Kartashov Evgeny Grigoryevich,

Doctor of science in Public Administration, Head of the Departmentof Project Management and General Professional Disciplines, Educational-Scientific Institute of Management and Psychology of the Higher Educational Institution "University of Management Education" of the National Academy of Pedagogical Sciences of Ukraine, 04053, Kiev, Str. Sichovykh Striltsiv, 52-a, tel.: (067) 61423 53,e-mail:yevgenkartashov@ gmail.com

ORCID: 0000-0001-6522-5508

\title{
Картамов Свген Григорович,
}

доктор наук з державного управління, завідувач кафедри управління проекта-

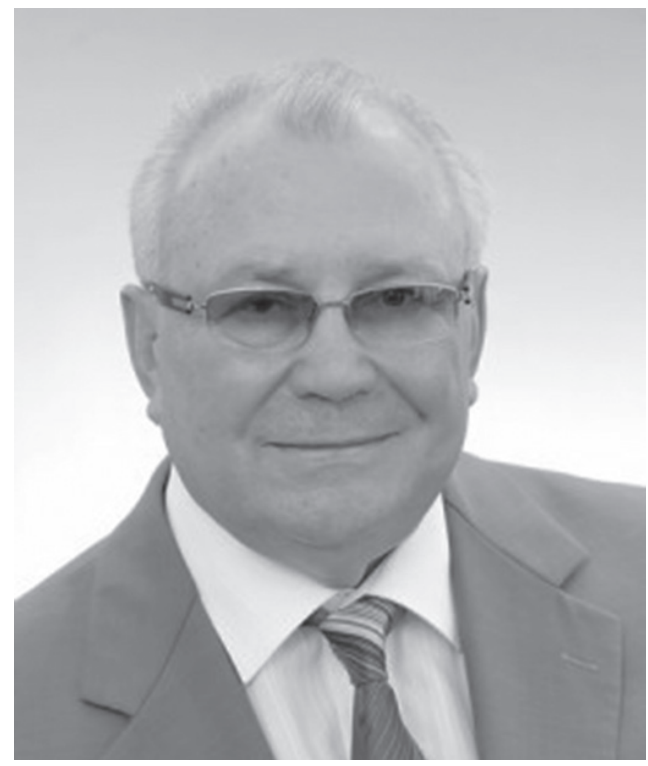
ми та загальнофахових дисциплін, Навчально-науковий інститут менеджменту та психології ДВНЗ “Університет менеджменту освіти” Національної академії педагогічних наук України, 04053, Киів, вул. Січових Стрільщів, 52-а, тел.: (067) 61423 53, e-mail:yevgenkartashov@gmail.com

ORCID: 0000-0001-6522-5508

\section{Карташов Евгений Григорьевич,}

доктор наук по государственному управлению, заведующий кафедрой управления проектами и общепрофессиональных дисииплин, Учебно-научный институт менеджмета и психологии ГВУЗ “Университет менеджмента образования” Национальной академии педагогческих наук Украины, 04053, Киев, ул. Сечевых Стрельчов, 52-а, тел.: (067) 61423 53,e-mail:yevgenkartashov@gmail.com

ORCID: 0000-0001-6522-5508

DOI https://doi.org/10.31618/vadnd.v1i11.25

\section{EUROPEAN LESSONS OF DECENTRALIZATION}

Abstract. The role of the state in the processes of European integration and decentralization is analyzed, the factors of threats for it are determined. The following common features of decentralization processes in the EU member states are highlighted as strengthening the role of the regional level, the need to choose between different models of separation of powers between different levels of government (exclusive or joint authority) and the search for ways to adequately finance transferred powers. Decentralization also actualizes the problem of territorial inequality and patronage for European countries. It is proved that the national state is a central actor in the process of decentralization, despite the fact that this process creates certain threats to the state itself. On the one hand, the EU as a 
supranational organization has already limited some aspects of the sovereignty of its member states, in particular, in the area of monetary policy. With the deepening of European integration, the powers of national states and in other areas are increasingly limited. On the other hand, the gradual increase in the share of powers conveyed by the state to decentralized and regional authorities further weakens its role. Moreover, the increasing influence of liberalism on state policy and the introduction of competition among the main providers of public services also limits the possibility of the state's influence on its internal policies. Such a dynamics gives grounds for questioning the ability of states to effectively manage their territories. At the same time, it was noted that in most EU member states, the bodies of state power have long been the guarantor of national unity in both social and territorial terms. Such a "unity of opposites" (decentralization and centralization) is unlikely to change in the medium term.

Keywords: decentralization, powers, subsidiarity, inequality, integration, region, local self-government.

\section{ЄВРОПЕЙСЬКІ УРОКИ ДЕЦЕНТРАЛІЗАЦЇ̈}

Анотація. Проаналізовано роль держави у процесах європейської інтеграції та децентралізації, визначено чинники загроз для неї. Виділено такі спільні риси децентралізаційних процесів у державах - членах $\mathrm{CC}$, як посилення ролі регіонального рівня, необхідність вибору між різними моделями поділу повноважень між різними рівнями державного управління (виключні або спільні повноваження) та пошук шляхів належного фінансування переданих повноважень. Децентралізація також актуалізує для європейських країн проблеми територіальної нерівності та патронажу. Доведено, що національна держава є центральним актором у процесі децентралізації попри те, що цей процес формує певні загрози для самої держави. 3 одного боку, Євросоюз як наднаціональна організація вже обмежила деякі аспекти суверенітету своїх держав-членів, зокрема, у сфері здійснення монетарної політики. По мірі поглиблення європейської інтеграції дедалі більше обмежуються повноваження національних держав і в інших сферах. 3 іншого боку - поступове збільшення частки повноважень, що передаються державою децентралізованим та регіональним органам влади, ще більше ослаблює іiі роль. Понад те, дедалі більший вплив лібералізму на державну політику та запровадження конкуренції між основними постачальниками державних послуг також обмежує можливості впливу держави на iï внутрішню політику. Така динаміка дає підстави ставити під сумнів спроможність держав ефективно управляти своїми територіями. Водночас відзначено, що в більшості держав - членів СС саме органи державної влади вже тривалий час $е$ гарантом національної єдності і в соціальному, і в територіальному вимірах. Така “єдність протилежностей” (децентралізації і централізації) навряд чи зміниться у середньостроковій перспективі.

Ключові слова: децентралізація, повноваження, субсидіарність, нерівність, інтеграція, регіон, місцеве самоврядування. 


\section{ЕВРОПЕЙСКИЕ УРОКИ ДЕЦЕНТРАЛИЗАЦИИ}

Аннотация. Проанализирована роль государства в процессах европейской интеграции и децентрализации, определены факторы угроз для нее. Выделены следующие общие черты децентрализационных процессов в государствах - членах ЕС, как усиление роли регионального уровня, необходимость выбора между различными моделями разделения полномочий между различными уровнями государственного управления (исключительные или совместные полномочия) и поиск путей надлежащего финансирования переданных полномочий. Децентрализация также актуализирует для европейских стран проблемы территориального неравенства и патронажа. Доказано, что национальное государство является центральным актером в процессе децентрализации, несмотря на то что этот процесс формирует определенные угрозы для самого государства. С одной стороны, Евросоюз, как сверхнациональная организация, уже ограничила некоторые аспекты суверенитета своих государств-членов, в частности, в сфере осуществления монетарной политики. По мере углубления европейской интеграции все больше ограничиваются полномочия национальных государств и в других сферах. С другой стороны, постепенное увеличение доли полномочий, передаваемых государством децентрализованным и региональным органам власти, еще больше ослабляет его роль. Более того, все большее влияние либерализма на государственную политику и внедрение конкуренции между основными поставщиками государственных услуг также ограничивает возможности влияния государства на ее внутреннюю политику. Такая динамика дает основания ставить под сомнение способность государств эффективно управлять своими территориями. В то же время отмечено, что в большинстве государств членов ЕС именно органы государственной власти уже длительное время являются гарантом национального единства и в социальном, и территориальном измерениях. Такое “единство противоположностей” (децентрализации и централизации) вряд ли изменится в среднесрочной перспективе.

Ключевые слова: децентрализация, полномочия, субсидиарность, неравенство, интеграция, регион, местное самоуправление.

Formulation of the problem. Decentralization processes taking place in every member state of the EU. A common feature of these processes is strengthening the role of regional and local authorities, a review of their relations with the Central government of the state. The differences in decentralization due, in particular, the size of the state, form of state structure, level of development of local self-government, socio-economic factors (level of education of its citizens, the degree of social cohesion), which determines the features of territory management at local and regional levels. However, the values that underlie the European community remains unchanged. 
Analysis of recent researches and publications. The problems of decentralization is the subject of study of many branches of science such as Economics, political science, philosophy, public administration, etc. This demonstrates the complexity of the problem and the impossibility of its solution only by traditional methods of scientific research and modern management system.

We can noted American and English scientists who investigated the background and practice associated with the economic problems of decentralization: Conn M., John Lochley, M. Roseland, John.-M. Fontaine, P. Hamel, G. Haughton and others. System and support local development was considered by R. Bingham, F. Bir, G. Green, L. Cary, R. Pitman and others. The issues of development of territorial communities researched by Russian scientists, namely: P. Belenchuk, R. Brusac, V. Voronkova, A. Goshko, G. Drobenko, V. Campo, I. Kozyura, V. Kuybida, V. Mamonova, N. Orlate etc. Regional and local government were analyzed by V. Vojtowicz, J. Dechtiarenko, O. Kilievich, V. Knyazev, V. Kravchenko, N. Nizhnik, M. Pukhtynskiy etc.

However, in the Ukrainian science, the issues of the integrated consideration of European lessons of decentralization remain inadequately researched.

Formulation of the objectives (purpose) article. The purpose of this article is to develop theoretical foundations and measures to improve the domestic approaches to decentralization based on European practice.

Presentation of the basic material. In the Preamble of the Charter of fun- damental rights of the European Union States that it "promotes the preservation and development of common values while respecting the diversity of cultures and traditions of the peoples of Europe, as well as the national identities of the member States and the organization of their public authorities at national, regional and local levels [1]. The principle of subsidiarity applies only to relations between the EU and member States and doesn't affect the internal structure of the latter. Accordingly, the process of decentralization takes place within the territory of the States.

As follows from the provisions of the European Charter of local selfgovernment, strengthening of selfgovernment in the different European countries is an important contribution to the building of Europe on the principles of democracy and decentralization of power, and the right of citizens to participate in public Affairs is one of the democratic principles shared by all member States of the Council of Europe. However, decentralization is also a requirement for good management, since "the existence of local authorities with real responsibilities can provide an effective and close to the citizen administration".

The national state is the Central actor in the decentralization process, despite the fact that this process creates certain threats for the state. On the one hand, the EU as a supranational organization has already restricted some aspects of the sovereignty of its member States, in particular, in the implementation of monetary policy. With the deepening of European integration, the powers of national states and 
in other areas are increasingly limited. On the other hand, the gradual increase of powers that are transferred to decentralized government and regional authorities, further weakening its role. Moreover, the increasing influence of liberalism on public policy and the introduction of competition between the main providers of public services also limits the state's influence on its domestic policies. This dynamics gives grounds to doubt the ability of States to effectively manage their territories. However, it should be recognized that in most member States of the EU that public authorities has long been the guarantor of national unity and social and territorial dimensions. This "unity of opposites" (decentralization and centralization) is unlikely to change in the medium term.

That is, the source of the threats to the state isn't decentralization as such, but above all the number of other factors, including economic and social exclusion, increasing imbalances in the development of territories, economic globalization, etc. Globalization, by definition, leads to the erosion of economic, cultural and other boundaries. Meanwhile, the decentralization, on the contrary, allowing each territory to maintain and develop their identity.

Nation-state continues to function as the main actor of the control areas. According to national constitutions and other laws it's authorized to organize regional and local government as one of the main foundations of democratic governance. Citizens, having had an opportunity to solve and solving local problems, gain the necessary knowledge and experience important for effective participation in political life at the national level.

Decentralization primarily involves the provision of regional and local authorities a degree of independence that secured the national law. Discussions that often arise (in particular, on the number of levels of government) seem a bit artificial. So, municipalities are the components of the state system of each country, although different in size, organization and legal status. At the same time, they have certain common preferences and common problems: they are closest to citizens and are responsible for providing services that are most in need citizens in everyday life. The regional level corresponds to the levels NUTS 1 and NUTS 2 according to the European nomenclature of territorial units for statistics [2] and, in some States absent using a small size of the territory (Luxembourg) or create deconcentrating areas (Greece, Portugal). Also in several States formed an intermediate level between municipality and region - Department (France), province (Italy), County (Poland). These three levels form the basic structure of the control areas in most member States of the EU.

In each country, the method of organization of decentralized authorities connected with its history, political and management culture, economy, social experience. Relevant differences make it impossible for the development and implementation of common (universal) EU model. However, there is some similarity in the approaches to solving a number of problems. First of all it concerns the increased administrative role of the regional level. In federal or highly regionalized countries ter- 
ritorial subjects of the federation (regions, lands) a long time at discretion resolved issues of the internal device. Because of it even the unitary states incorporate regions with the special status now. In some cases, is the Islands (Azores, Corsica, Madeira), other - regions within the whole of government of the territories (Scotland, Ireland, Wales in the UK, the region of Ile-deFrance in North-Central part of the French Republic). The movement toward a further diversification of institutions and institutions also affects the system of local government in Federal and unitary States. In particular, States are forced to reform the administrative-territorial system subject to the availability of underdeveloped rural areas, the need to create conglomerates of cities and the development of intermunicipal cooperation. So France is traditionally the unitary state, depending on the size of the isolated community of municipalities, community of agglomerations, urban communities, and in the near future metropolis. Such complexity means the only attempt to harmonize the functioning of very different territories within the single state, and that determines the popularity of decentralization, able to take into account the diversity of administrative-territorial units of the country.

The next problem, you have to address Europe in the course of decentralization lies in the choice between equality and hierarchy in the relations between the different regional and local institutions. In the French Constitution, for example, enshrined the principle that no local authority may not exercise the power or carry out supervision over other authorities, but in reality this is more of a formality than a practice. Instead, in the legal field of Germany, the hierarchy in the relationship between the different levels of government is given priority: the legal acts adopted by the land authorities obligatory for local self-government bodies located in their territories, and the higher level of regional (local) authorities has the right to supervise for the activities of the lower. Both the first and the second approaches have disadvantages. In the French system of formal equality that doesn't correspond to the actual practice of relations of subordination between the various levels of government, isn't conducive to the development of cooperation between regions, departments or municipalities, and doesn't exclude the possibility of competition between them, which leads to blurring of responsibilities. The German-elected hierarchy contributes to the re-concentration of power at the land level and contradicts the formal imperatives of decentralization. However, despite the diversity of national experiences, the idea of providing a regional level of responsibility for the maintenance of unity of system of local self-government finds more and more supporters.

Clear separation of powers between the state and various local and regional authorities is a basic requirement for effective public management. The European Charter of local self-government in article 4 notes that "the basic powers and functions of local governments are determined by the Constitution or by law. However, this provision doesn't preclude the granting to local governments powers and responsibilities for specific purposes in accordance 
with the law. Local authorities within the law have every right to freely decide any question not withdrawn from their competence and which isn't assigned to any other institution. The Charter also States that the powers conferred upon local authorities, as a rule, should be full and exclusive. They cannot be suspended or restricted other Central or regional authority, unless required by law" [3].

The mechanism of the exclusive competence applies in Belgium, where every authority is vested with the authority dedicated only to him: the issues related to sovereignty are the responsibility of Federal institutions; cultural issues, health care and social assistance fall within the competence of the communities, and questions of housing and communal services partially within the scope of competence of the regions. Exclusive authority means that there can be no interference from the Federal government. The principle of shared authority is practiced in a federated Germany. According to the Constitution the Parliament of the Federation has exclusive powers in clearly defined areas; and the land are denied the right to adopt legislation in several areas (foreign Affairs, defense, free movement of goods and people, credit and monetary policy, customs, railway, postal and telecommunication services), except when Federal law allows you to adjust a certain relationship. Exclusive powers of the land are determined by special provisions of the Constitution (culture, education, local business and the like). According to the Constitution of the land guarantees municipalities the right to regulate relations in the framework of their own responsibility and in the framework of the law, primarily deals with all issues of local communities: local public transport, local roads, supply of gas, water, electricity, construction and urban planning, construction and support of primary and secondary schools, theaters, museums and hospitals, sports infrastructure. However, according to most experts, Germany moves to a more complex system of separation of powers that is increasingly difficult to understand, therefore, from time to time there are calls for revision and a clearer definition of powers between the federal parliament and the lands, especially given the increasing impact of EU legislation on the domestic policy of the states -members

In Italy the separation of emergency powers between state and regions is more consistent with the best interests of Rome. A number of exclusive powers assigned to the public authorities of Spain and the Autonomous communities. It's obvious that the system of emergency powers helps the citizens to understand and know exactly what kind of authority is responsible for a specific field. It should be noted that this mechanism doesn't exist in his "perfect pure" form, because there are cases of exceptional powers, coincident with concentrated powers. Moreover, strict separation of powers doesn't always provide effective management of the territories, particularly as you get closer to the basic level of the territorial structure of the state.

The modern experience of decentralization gives more arguments in favor of practices that introduced mechanisms of joint powers tested first of all, unitary States: each level of go- 
vernment is responsible for matters corresponding to his level, and it's open to interference by other authorities of the same or higher level. In France the municipalities are responsible for primary education; the Department for social services and colleges; the regions for land management, training and higher education. Poland is also an example of collaborative models of authority: the commune and the province are engaged in water supply and sanitation and maintenance of public roads. When it comes to social services, education and culture, all three levels are responsible for them (gmina, county and voivodship). This approach has certain advantages: it creates favorable conditions for the development of cooperation between the various authorities; increases the possibility of raising the funding needed to implement important for the local and regional level projects. Among the disadvantages of this approach is that it complicates the understanding of citizens, administrative body which meets sphere.

If decentralization involves the division of powers between the state and the various levels of regional and local self-government, it means that this division should be clear and accompanied by adequate financial mechanisms. Decentralization cannot be used for the deliverance of the state from liability for those services that she is unable to provide for lack of financial resources. Decentralization is aimed at providing safeguards for effective management at lower levels of elected bodies based on democratic principles.

This is stated in article 9 of the European Charter of local self-government: "local self-government Bodies are entitled within national economic policy to adequate financial resources of their own, which they may dispose freely within their powers. The financial resources of local governments match the powers provided by the Constitution or by law. ... Financial system that constitute the core resources of local governments are sufficiently diversified and flexible, and should provide the opportunity to bring available resources to the extent practicable, in accordance with the actual increase in the cost of the tasks they perform".

Also, the mechanism of financial equalization should operate. The Charter identified two fundamental principles: the principle of involving the local authorities own resources, which it may freely dispose of (responsibility principle) and the principle that these resources should allow it to execute its powers in the usual way (principle of adequacy). However, in practice, many European countries, especially in situations of economic crisis, the empowerment of local authorities is often ahead of its authorization for sources to produce resources to the extent necessary for the proper implementation of these powers.

The deepening of decentralization also requires the solution of two problems: cavities and patronage. Inequality is directly connected with the nature of decentralization as such, as provides for the transfer of authorities to regional and local levels certain powers of the Central government, delegation of responsibility, together with appropriate financing. However, in each country, the bodies of regional and local authorities have different possibilities of financing their activities in providing 
services to the population. The least developed municipalities and regions find themselves in a situation in which provide public services poorer quality and in smaller volume than more affluent and, therefore, are forced to seek additional sources of budget revenues, including facing the need to increase the tax burden on residents and businesses. To avoid this threat, decentralization must be complemented with mechanisms aligned with respect to the distribution of public resources across decentralized institutions. A strong territory - developed autonomy - at least "without enthusiasm" refer to such solidarity.

The patronage is the result of inequality of relations between regional or local authorities and "patron" the citizens who receive protection or benefits in exchange for loyalty or political support. The more authority and resources transferred to local and regional level, especially the political forces are interested in the maximum control of the relevant representative bodies, allocating local budget funds for project financing and disposing of other material resources of society to meet the needs of their most loyal voters. Pretty quickly the party affiliation becomes the defining characteristic for employment in local/regional authorities or obtaining contracts. So for certain regions of Italy typical of the close connection of political parties with mafia groups, which determine local policy. That is, for several election cycles, the political party that "bribing" so voters can subdue the municipality or the region, turning them into their fiefdom, rewarding its members and supporters, while creating artificial obstacles to the activities of the opposition forces, using undemocratic methods. Combating this phenomenon must be integrated, in particular, to include activities such as increasing transparency in work of public authorities, rule of law, strengthening of responsibility and accountability of officials and members of representative bodies, effective policies of prevention and combating of corruption at all administrative levels.

It's important to prevent abuse of certain groups of potential elections, and other forms of "participatory democracy", the tools of which generally increases along with decentralization changes. We need a legislative fuses from the use of decentralization and its inherent democratic procedures in the interests of certain groups and individuals to the detriment of the communities.

\section{Conclusions and prospects for fur-} ther research. Despite a fairly widespread concern that decentralization in the context of globalization and deepening European integration forms an inevitable and insurmountable threat to the sovereignty of European Union States, these States continue to play a functionally transformed, but, as before joining the EU, the leading role in the management of their territories. One manifestation of this is that each of the States of the European Union develops and implements its own specific national decentralization reform as a response to the global public demand for the development of democracy, improving the efficiency of social control, his approach to people and their needs.

In the process of such reform in the most troubled look practice with the 
advantage of the introduction of the exclusive competence of the Central, regional and local levels of government. The greatest show validity of the model of decentralization, focused on the optimal combination of power and capacity of Central, regional and local authorities. Such models contribute to better mobilization and more efficient use of resources for the implementation of projects jointly undertaken by governments at various levels in the interests of communities and citizens. At the same time, they aren't deprived of such shortcoming as blurring the accountability of these bodies for the progress and results of their work.

To problematic aspects of decentralization of governance in the $\mathrm{EU}$ belongs to such reorganization of the financial and economic system that the resource was provided by the national government and the joint interests of the EU, together with the endowment of bodies of regional and local self-government in these countries financial capabilities, sufficient for the proper realization of the whole complex of their powers, in particular, given the importance of conflict-free alignment of territorial imbalances.

\section{REFERENCES}

1. Charter of Fundamental Rights of the European Union (Nice, 7 December 2000), available at: http://zakon2. rada.gov.ua/laws/show/994_524 (Accessed 1 Okt 2017).

2. Nomenclature of territorial units for statistics, available at: http://ec.europa. eu/eurostat/web/nuts (Accessed 1 Okt 2017).

3. The Charter of Fundamental Rights of the European Union (Strasbourg, 15 October 1985), available at: http://zakon2.rada.gov.ua/laws/show/994_036 (Accessed 1 Okt 2017).

\section{СПИСОК ВИКОРИСТАНИХ ДЖЕРЕЛ}

1. Хартия основных прав Европейского Союза (Ницца, 7 декабря 2000 года) / URL: http://zakon2.rada.gov. ua/laws/show/994_524 (дата звернення: 01.10.2017).

2. Nomenclature of territorial units for statistics / URL: http://ec.europa.eu/ eurostat/web/nuts (дата звернення: 01.10.2017).

3. Свропейсъка хартія місцевого самоврядування (м. Страсбург, 15 жовтня 1985 року) / URL: http://zakon2. rada.gov.ua/laws/show/994_036 (дата звернення: 01.10.2017). 